OPTIONS FOR HOMES IN METRO VANCOUVER: THE CREATION OF COST-EFFECTIVE HOME OWNERSHIP OPPORTUNITIES

by

Graham Plant

BA, Simon Fraser University, 2010

A Major Research Paper

presented to Ryerson University

in partial fulfillment of the requirements for the degree of

Master of Planning

In

Urban Development

Toronto, Ontario, Canada, 2014

(C) Graham Plant 2014 


\section{Author's Declaration}

I hereby declare that I am the sole author of this major research paper. This is a true copy of the major research paper, including any required final revisions, as accepted by my examiners. I authorize Ryerson University to lend this major research paper to other institutions or individuals for the purpose of scholarly research. I further authorize Ryerson University to reproduce this major research paper by photocopying or by other means, in total or in part, at the request of other institutions or individuals for the purpose of scholarly research. I understand that my major research paper may be made electronically available to the public. 


\title{
OPTIONS FOR HOMES IN METRO VANCOUVER: THE CREATION OF COST-EFFECTIVE HOME OWNERSHIP OPPORTUNITIES
}

\author{
(C) Graham Plant, 2014 \\ Master of Planning \\ In \\ Urban Development \\ Ryerson University
}

\begin{abstract}
Housing affordability is a frequently discussed issue in many Canadian cities; none more than Vancouver and the surrounding region. Data on housing stress in Metro Vancouver indicates the problem is real, and that home ownership is out of reach for most low and moderate income earners in the region. A preliminary feasibility analysis indicates that a model created by Options for Homes, a non-profit housing provider founded in Toronto, would produce units for significantly less than comparable private developments. While expanding Options for Homes would not be a panacea for affordability in the region, and there are a number of associated challenges with applying the model in Metro Vancouver, there is merit to the further exploration of a model that provides below-market home ownership opportunities to households currently priced out of the housing market.
\end{abstract}




\section{Acknowledgements}

I would like to thank my supervisor, David Amborski, as well as my second reader, Sean Gadon, for their help and guidance with this major research paper. I would also like to thank Michel Labbe and Paul Tamale from Options for Homes for their assistance; this paper was not commissioned for or approved by Options for Homes, but they were supportive and responsive whenever I had questions or requests. Finally I would like to thank my wife Sarah and dog Joey for keeping me sane throughout the process. 


\section{Contents}

Introduction

Section 1 - Affordable Home Ownership $\quad 2$

What is "Affordable Housing"? 2

Defining the Problem in Metro Vancouver 3

Public Sector Interventions and Home Ownership 7

International 8

National $\quad 8$

Provincial $\quad 9$

Municipal 9

Below-market Home Ownership 10

Inclusionary Zoning - Vancouver and Elsewhere $\quad 10$

Attainable Home Ownership Program - Calgary, Alberta 11

Habitat for Humanity 12

Lessons from Case Studies $\quad 12$

Section 2 - Options for Homes $\quad 14$

Overview 14

How the Options Model Works 15

How Options Creates Affordable Home Ownership Opportunities 16

1. Lower Production Costs 16

2. The $2^{\text {nd }}$ Mortgage 17

3. Lower Monthly Fees 18

Additional Cost Saving Mechanisms 19

Site Selection $\quad 19$

Home Ownership Alternatives $\quad 20$

Critiques and Limitations of Options for Homes $\quad 21$

Unit Affordability vs. Household Affordability $\quad 22$

Section 3 - High-Rise Options in Metro Vancouver $\quad 23$

Downtown Vancouver 25

Central Burnaby $\quad 26$

$\begin{array}{ll}\text { Central Surrey } & 27\end{array}$

Central Coquitlam 28

High-Rise Analysis $\quad 29$

Section 4 - Options Carrying Costs and Affordability 30

Carrying Costs - Central Burnaby $\quad 30$

Carrying Costs - Vancouver, Surrey, and Coquitlam 33

Affordability 33

Analysis - Carrying Costs and Affordability $\quad 35$ 
Section 5 - Mid-Rise Options in Metro Vancouver 36

Surrey and Coquitlam Mid-Rise - Project Cost $\quad 37$

Surrey and Coquitlam Mid-Rise - Carrying Costs and Affordability 38

Section 6 - Findings and Recommendations $\quad 39$

Findings $\quad 40$

Creating Affordable Housing Units through New Housing 40

Compromising Location for Affordability $\quad 41$

Recommendations $\quad 41$

1. Deferral of municipal fees and charges 41

2. Leasing of surplus lands 42

3. Incorporating $2^{\text {nd }}$ mortgages into private developments 42

4. Determine the effectiveness of Options for Homes affiliates 43

5. Outline the benefits of below-market home ownership investment 43

$\begin{array}{ll}\text { Conclusion } & 45\end{array}$

Appendix - Pro Forma Assumptions $\quad 46$

$\begin{array}{ll}\text { Reference List } & 47\end{array}$ 


\section{List of Tables}

Table 1 - Options High-Rise in Downtown Vancouver

Table 2 - Options High-Rise in Central Burnaby

Table 3 - Options High-Rise in Central Surrey

Table 4 - Options High-Rise in Central Coquitlam

Table 5 - Central Burnaby Listings, High-Rises Built 2010 to 2014

Table 6 - Central Burnaby Unit Prices

Table 7 - Central Burnaby Mortgage Payments

Table 8 - Central Burnaby Carrying Costs

Table 9 - Downtown Vancouver Carrying Costs

Table 10 - Central Surrey Carrying Costs

Table 11 - Central Coquitlam Carrying Costs

Table 12 - Carrying Cost Summary Table

Table 13 - Minimum Income Unit Requirements

Table 14 - Options Mid-Rise in Surrey and Coquitlam

Table 15 - Mid-Rise Carrying Cost Summary Table

Table 16 - Mid-Rise Minimum Income Unit Requirements 


\section{List of Figures}

Figure 1 - Tenure, Metro Vancouver Households

Figure 2 - Housing Stress, Metro Vancouver Households

Figure 3 - Housing Stress by Tenure, Metro Vancouver Households

Figure 4 - Median Income and Shelter Costs by Tenure, Metro Vancouver Households

Figure 5 - Median Income for Housing Stress Presence, Metro Vancouver Households

Figure 6 - Housing Stress, Tenure, and Mortgage Presence, Metro Vancouver Households

Figure 7 - Housing Stress by Tenure and Age Group, Metro Vancouver Household 


\section{Introduction}

Housing affordability matters. The more a household spends on costs associated with housing, the less they have left over to pay for other necessities such as food, clothing, transportation, and leisure activities. Vancouver and the surrounding region, henceforth referred to as Metro Vancouver, has an affordability problem. Ostensibly on a weekly basis a domestic or international report is released that ranks it among the least affordable cities in the world, with the growth housing prices rapidly outpacing the growth of incomes. The supply of land in Metro Vancouver is restricted by the Pacific Ocean to the west, the Coastal Mountain Range to the north, and the United States border to the south; with such prominent natural and man-made boundaries, it is inevitable that the supply of housing struggles to keep up with the demand. Policy makers must be creative and innovative to ensure the population of the region has access to housing, a vital public good, at a price that they can afford.

Municipalities across Metro Vancouver are grappling with the issue of affordability. Given the fiscal constraints of provincial and federal governments, and the limited revenue tools available to municipalities, models that create affordable housing using little or no public subsidy deserve further exploration. This paper will examine the feasibility of a model created by Option for Homes, an Ontario-based non-profit organization, and its ability to create home ownership opportunities for households currently unable to access the housing market. A separate organization, Options for Homes of Greater Vancouver, currently has one 30 unit building approved in Metro Vancouver. This feasibility analysis is meant to explore further possibilities for the Options model, and what the impact on affordability would be. 


\section{Section 1 - Affordable Home Ownership}

What is "Affordable Housing?"

Housing affordability is a complex and nuanced issue. It applies to those that are housed, and not outright homelessness, though the implications of the former have significant ramifications for the latter (Hawtrey, 2009). Housing affordability is focused on the segment of the population that have jobs and incomes, but experience, either temporarily or permanently, financial pressure from the cost of their housing. This pressure will be referred to throughout the paper as "housing stress".

Households suffer from economic stress when too much of their income is spent on housing, reducing their ability to meet other basic needs such as food, clothing, and transportation. The accepted benchmark that determines the presence of housing stress is when households must spend 30 percent of their total before-tax income on shelter-related expenses. This is the benchmark used by Statistics Canada in their National Household Survey, and the one that will be used throughout the remainder of the paper. The international "rule of thumb" ratio was 25 percent until the early 1980s, but has consistently been 30 percent since then (Hawtrey, 2009). For renters, the total costs of housing are generally rent and utilities. For owners, shelter-related expenses include mortgage payments, property taxes, condominium fees, as well as maintenance and repairs, utilities and other municipal fees or service charges.

There are a range of problems associated with using housing affordability indices, especially one as simple as the ratio of housing costs to gross income. It does not take into account household size. A single individual can afford to spend more on housing than a family 
of five, who has to spend more on food, clothing, and other necessities. An additional problem is that there is no consideration of the transportation costs associated with where a household lives. The same household can afford to spend a greater proportion on housing if they are saving money on transportation. Furthermore, the ratio benchmark is a static measurement that does not address the sustainability of housing stress. A fulsome critique of the index used by Statistics Canada is beyond the scope of this paper, but Jewkes and Delgadillo (2010) provide a thorough analysis of the problems with conventional housing indices used by practitioners.

\section{Defining the Problem in Metro Vancouver}

As of the 2011 National Household Survey, there were 891,310 households in Metro Vancouver. Two-thirds of those households were owners, and one-third were renters (Figure

1). As seen in Figure 2, nearly one-third of households experience some form of housing stress

FIGURE 1: TENURE

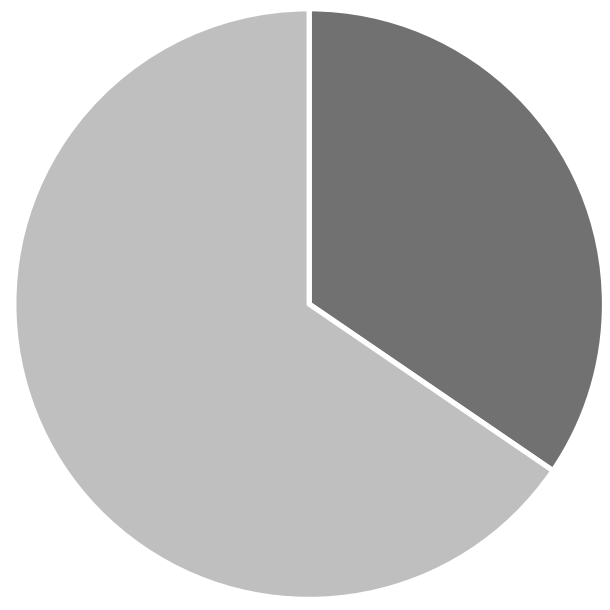

- Renters $\square$ Owners
FIGURE 2: HOUSING STRESS

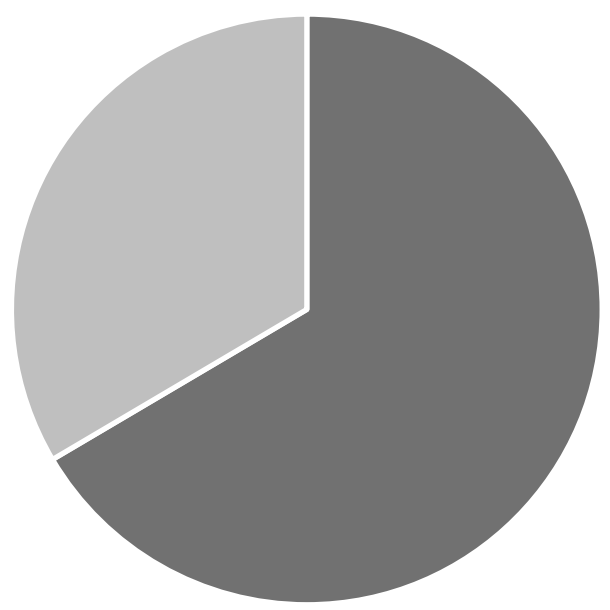

- No Housing Stress Housing Stress

Source: Statistics Canada, 2013 
by spending 30 percent or more of their before-tax income on shelter costs. 46 percent of renters experience housing stress, compared with only 28 percent of owners (Figure 3).

FIGURE 3: HOUSING STRESS BY TENURE

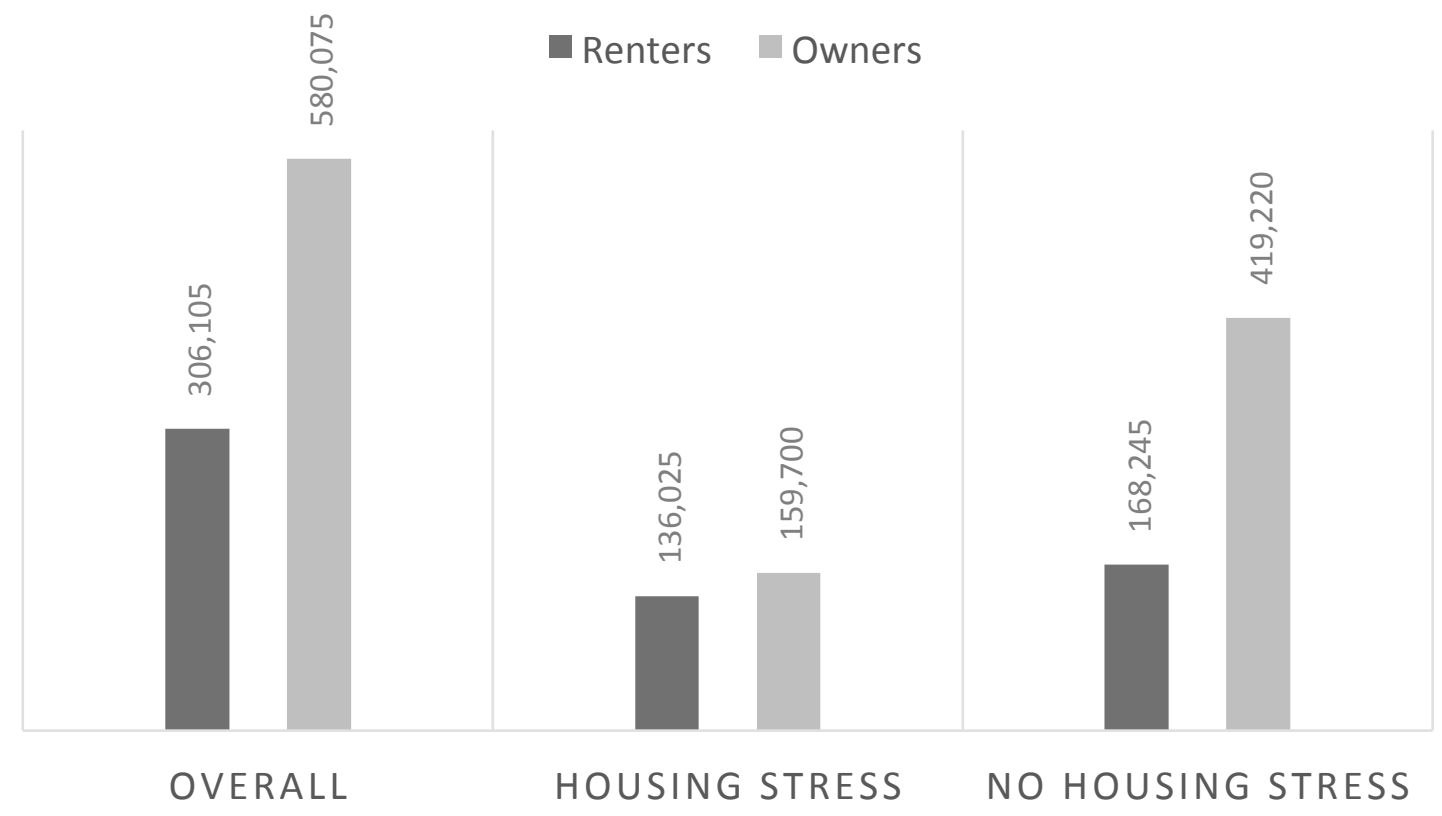

Source: Statistics Canada, 2013

This gap is further illustrated by Figure 4, a comparison of the median income and median shelter costs of renters and owners. Owners earn nearly double what renters earn, but their shelter costs are only a few hundred dollars a month more. 


\section{FIGURE 4: MEDIAN INCOME}

AND SHELTER COSTS BY

TENURE

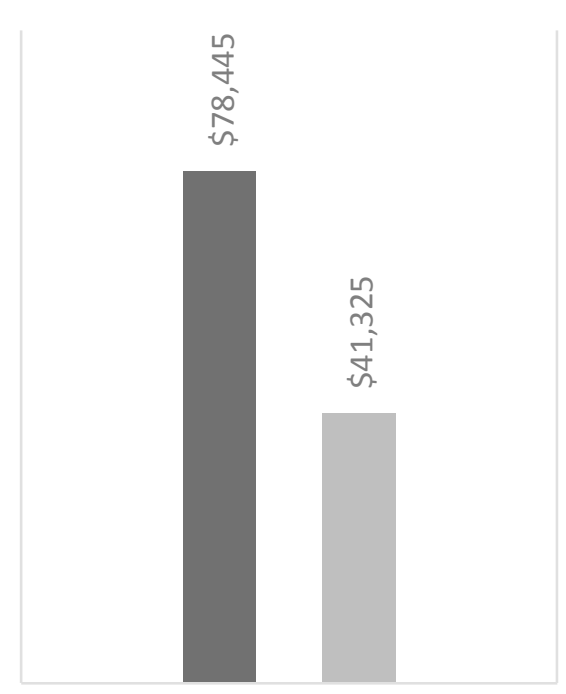

MEDIAN INCOME

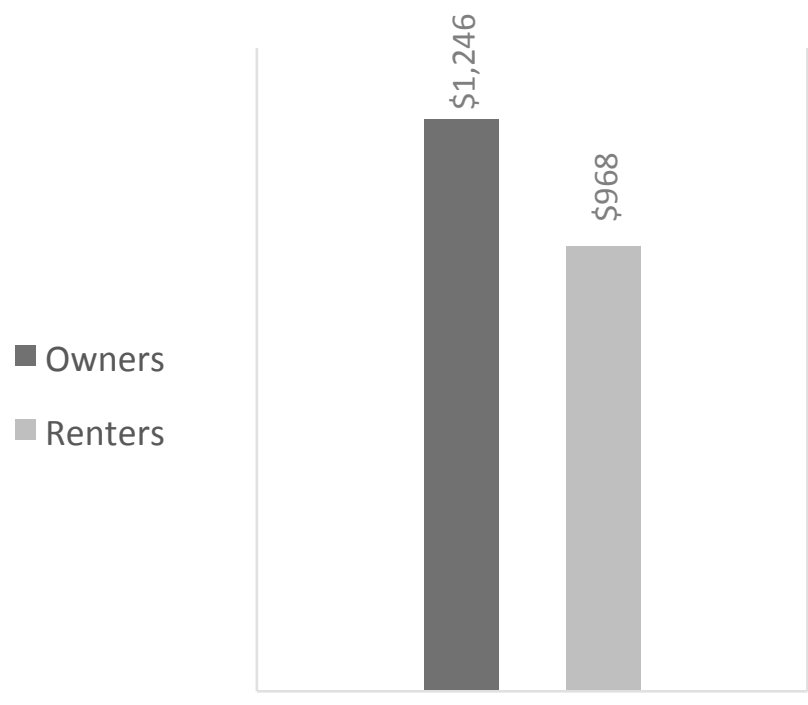

MEDIAN SHELTER COSTS

Source: Statistics Canada, 2013

Both elements of the housing affordability ratio are important when considering households experiencing housing stress. From an urban planning context, the cost of housing is the most frequently analyzed variable. However the effect of the second variable, income, cannot be overstated: high house prices are only a problem for those who can't afford them. The median income in Metro Vancouver in 2010 was $\$ 63,497$; the median income of those experiencing housing stress was $\$ 27,213$ (Figure 5). Raising incomes will help to alleviate housing stress as much as lowering the cost of housing. 
FIGURE 5: MEDIAN INCOME, HOUSING STRESS PRESENCE

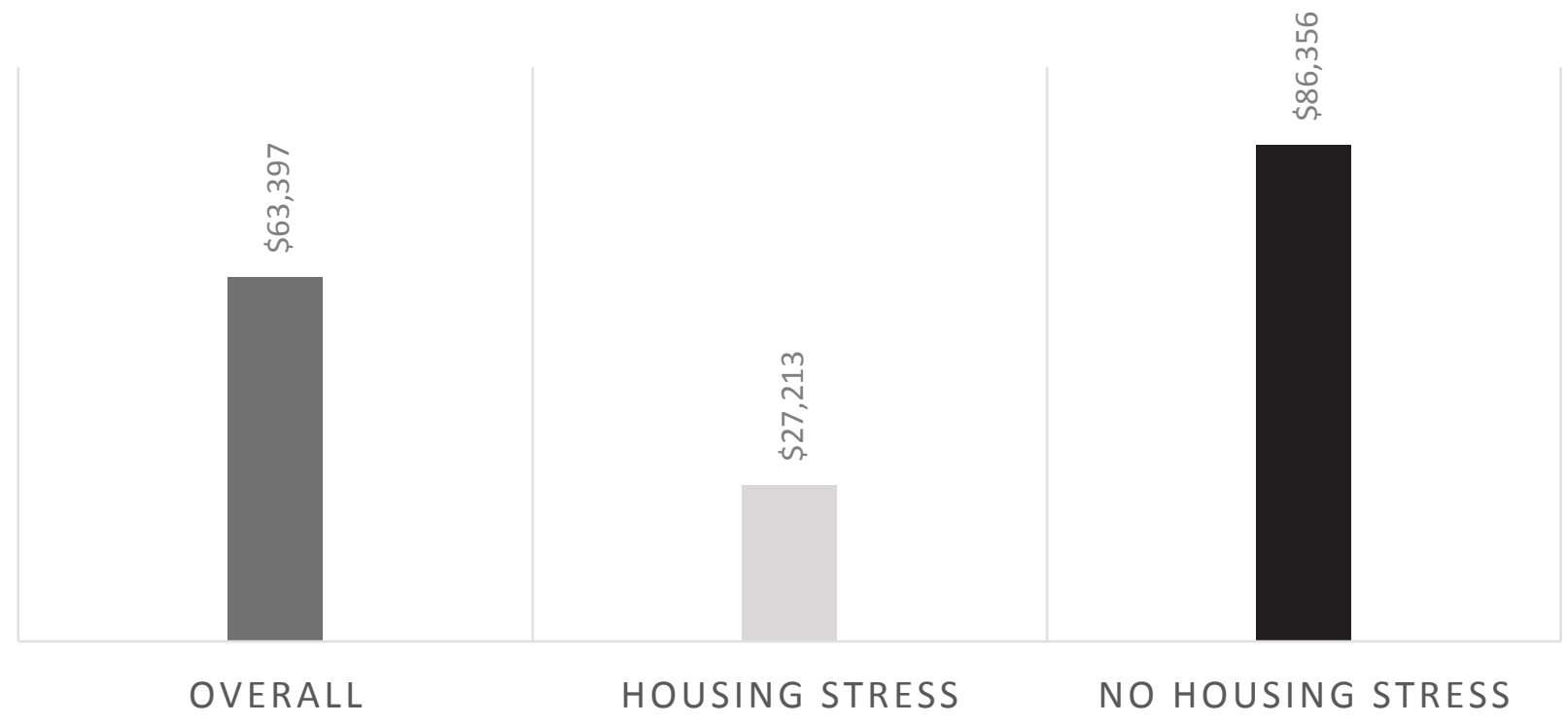

FIGURE 6: HOUSING STRESS, TENURE AND MORTGAGE

PRESENCE

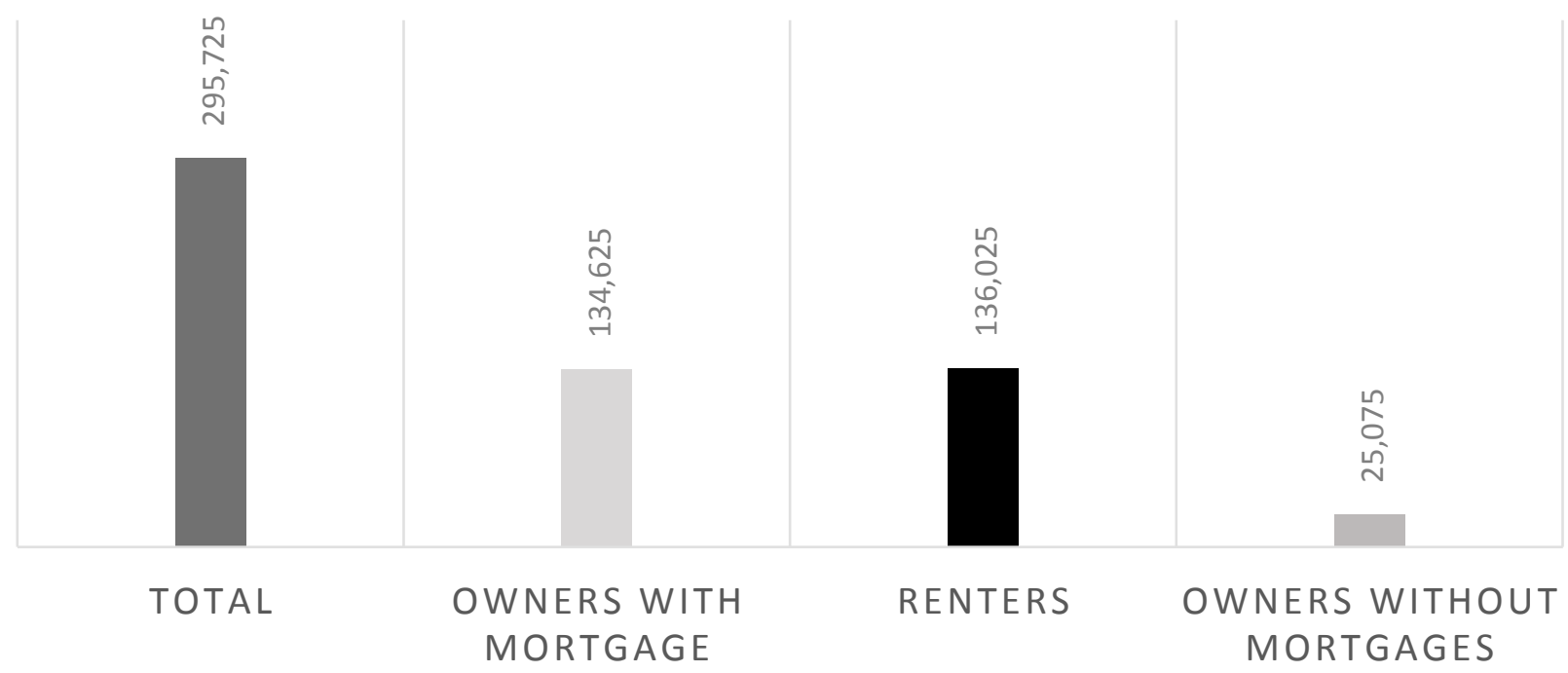

Source: Statistics Canada, 2013 
Of the nearly 300,000 households in Metro Vancouver experiencing housing stress, an approximately equal number are owners with mortgages and renters. However a clear distinction emerges between owners with mortgages and owners without mortgages. As evidenced in Figure 6, owners without mortgages are by far the smallest subgroup to experience housing stress.

If the widely accepted benchmark of spending 30 percent of household income on housing is used, it can be stated inarguably that Metro Vancouver has a problem with housing affordability. One-third of households face housing stress, and the problem is not isolated to owners or renters. Income is a key part of the equation, but housing stress is not only felt by low-income earners: 20 percent of Metro Vancouver households earning between $\$ 60,000$ and $\$ 79,999$ experience housing stress (Statistics Canada, 2013). Raising incomes and lowering the cost of housing are the keys to increasing the affordability of housing. The cost of housing can be lowered by reducing the cost of producing housing, but also by lowering the carrying costs of housing, and one of the easiest ways to lower the carrying costs of housing is to own your home outright after paying off a mortgage. If you want an affordable home in Metro Vancouver, make a lot of money, own a mortgage-free home, or ideally, do both.

\section{Public Sector Interventions and Home Ownership}

Whether home ownership is preferable to renting from a public policy perspective is beyond the scope of this paper, but pro-home ownership interventions have been in place in North America for decades, and their perseverance indicates either the reality or the perception that ownership remains a priority for households. Prioritizing home ownership 
inevitably leads to attempts to make housing more affordable or more accessible to a greater proportion of the population. As outlined below, there are many different layers of subsidies in the housing market, but this section does not address direct public subsidies for housing, instead focusing on the over 95 percent of households that participate in the conventional housing market (Statistics Canada, 2011).

Through government interventions, home ownership is encouraged both indirectly and directly. The expansion of highways and roadways, as well as zoning by-laws that restrict height and density, encourage the development of single-family homes, which indirectly encourages the development of owned dwellings. 85 percent of single-family homes are owner occupied, whereas more than 85 percent of dwellings in homes with more than three units are rented (Glaeser, 2011). Subsidizing sprawled, single-family home development indirectly encourages home ownership and discourages the development of rental stock. More directly, home ownership is subsidized in varying ways in different parts of the world and in Canada. International

The most significant direct subsidy to home ownership outside of Canada is the home mortgage interest deduction in the United States, which deducted roughly $\$ 70$ billion dollars in taxes in 2013 (Weicher \& Katz, 2013).

National

In Canada, mortgage interest is not tax deductible, but other federal and provincial policies exist to subsidize home ownership. A study found that housing spending by the Canadian federal government in 2009 totaled $\$ 17.1$ billion, with 93 percent of the expenditures benefiting home owners (Clayton, 2010). Policies include the First-time Homebuyer's Tax 
Credit, Senior Homeowner's Property Tax Grant, the non-taxation of capital gains on principal residences, and more.

Provincial

In British Columbia similar policies exist, including the B.C. Property Tax Deferment Program, Home Owner Grant, and First-time Home Buyer Property Transfer Tax exemption, again primarily targeting home ownership and not rental housing.

\section{Municipal}

Policy initiatives at the municipal level can also serve to increase the affordability of home ownership. In Vancouver, zoning for secondary suites and laneway housing has increased the supply of housing in single-family home neighbourhoods, and reduced parking requirements have reduced the cost of producing primarily ownership housing (Duffus, 2012).

Just as governments can make home ownership more affordable, regulation can make it less affordable or accessible. In 2011, the Canadian government shortened the longest amortization period available for mortgages with a down payment of less than 20 percent from 30 to 25 years. No longer being able to stretch a mortgage loan over 30 years means the monthly carrying cost of a home rises and becomes less accessible for some. At the provincial level, land-use policies that restrict developable land limit supply and drive up the cost of housing, and at the municipal level zoning by-law restrictions have the same effect.

These are only some of the many ways that government policy and legislation can influence the affordability of housing in a region, and the overall impact of government interventions on the housing market is well beyond the scope of this paper. The next section 
will narrow the scope to consider programs and initiatives that target income-earning households who struggle to either afford or access the conventional housing market.

\section{Below-Market Home ownership}

Below-market home ownership provides access to those households who struggle to afford or access the conventional housing market. Below-market housing can be achieved through both supply and demand strategies. The housing product can be made less expensively, which provides access to individuals who were previously priced out of the market because the product was too expensive. Or, financing can be made more accessible, which provides greater access to individuals who were priced out of the market because of one or more of the following barriers: saving for a down payment, the inability to qualify for a mortgage, or the inability to pay the carrying costs of a mortgage. A number of programs exist locally and internationally that attempt to create home ownership opportunities for households who are unable to access an appropriate level of housing through the conventional housing market. The list below is not exhaustive, but provides a snapshot of the types of programs available and the techniques used to provide housing at below market rates.

Inclusionary Zoning - Vancouver and elsewhere

Inclusionary zoning is an instrument used by municipalities that requires affordable housing be provided as a part of a market development. In Vancouver, the City requires 20 percent of units in major residential projects be designated as social housing, and in Burnaby the policy requires that 20 percent of units be "non-market housing". In Langford, British Columbia, Council adopted a " 1 in 15 " policy that states as a condition for the rezoning of new 
subdivisions, one of every 15 homes must be sold at a price well below market value (Metro Vancouver, 2012). The Langford model also charges $\$ 1,000$ for every residential unit created in multiples less than 15 and puts the funds in an Affordable Housing Reserve Fund, which ensures projects of every scale are contributing.

Weaknesses: Inclusionary zoning is a purely municipal tool that requires developers to build below-market units, and does not engage in any innovative supply or demand-side practices. Additionally, most inclusionary zoning policies require only large-scale residential developments to produce units, and thus place the burden on developers who build such projects.

Attainable Home Ownership Program - Calgary, Alberta

The Attainable Homes Calgary Corporation (AHCC), owned fully by the City of Calgary, offers moderate income families the opportunity for entry-level home ownership (Metro Vancouver, 2012). By leveraging their relationship with lawyers, insurers, banks and builders, the AHCC produces units in bulk at reduced prices. The buyer must produce a minimum deposit of $\$ 2,000$, but the remainder of the 5 percent down-payment is gifted, and not required to be paid back. When sold, a portion of the homes appreciated value goes back to the AHCC in a shared appreciation mortgage, a type of mortgage explained in detail further on in the paper. The program received $\$ 945,946$ in start-up funds from the Government of Alberta, but is designed to be self-sustaining beyond the initial start-up capital.

Weaknesses: Nearly \$1 million in public funding was required as start-up capital, and the units created thus far have been "attainable" to the first buyer only. 
Habitat for Humanity ("Habitat")

The mission of Habitat is to make affordable housing accessible to low-income families who could not otherwise afford a home (Habitat, 2014). They do this by building modest homes using volunteer labour and donated materials, and selling the homes to partner families with a required commitment of 500 volunteer hours. The families are then given a no-interest, no down-payment mortgage with monthly payments set at 25 percent of gross income. Habitat families must demonstrate need, be willing to make a significant time commitment to the organization, and also be able to repay the mortgage. Habitat is funded primarily by donations and fundraising, and is given additional support from the public sector, however is primarily a privately run, privately funded organization.

Weaknesses: The Habitat model is not self-sustaining, as it relies almost entirely on fundraising, donations, and public support to produce units for households. Furthermore, Habitat produces a low volume of units, as the units are costly to produce, there is a lengthy qualification process, and a substantial commitment is required by eligible households.

\section{Lessons from Case Studies}

Most below-market home ownership programs are run with significant support from the public or private sector, and the ongoing success of a below-market home ownership program in Metro Vancouver may depend on its ability to be self-sustaining. Given the fiscal capacity of governments across Canada and the limited appetite for additional public housing organizations, Metro Vancouver is limited in its ability to significantly improve the status quo through public funding or public programs. Moreover, they should not expect the private sector 
to carry the entire burden. A mix of solutions, run both publicly and privately, that target low and moderate income earners is required. The next organizational model, which will be explored in depth, targets a different demographic then Habitat for Humanity, focusing on moderate rather than low income earners. Options for Homes is a self-sustaining model of below-market home ownership with a track record of success, an established business model, and much like Habitat for Humanity, is willing to share their experience and expertise. 


\section{Section 2 - Options for Homes}

\section{Overview}

Options for Homes Non-Profit Corporation, hereafter "Options", was started in Toronto, Ontario, in 1993. The founder, urban planner Mike Labbe, remains the President and CEO of the organization. Options is an organization dedicated to creating cost-effective home ownership opportunities to households who are typically unable to access the traditional housing market. Affiliates that use the Options model, or variations on it, now exist regionally across Ontario, domestically in Quebec and British Columbia, and abroad in Cameroon, Kenya, Peru, Columbia, and Bangladesh. Together with their affiliates, Options has built over 3,700 units in 20 years (Options for Homes, 2012). The Options model has expanded beyond housing and created Options for Cars, a non-profit car sharing co-operative, and Options for Green Energy, a developer of community-financed green energy. All three are part of the Options Group of Companies, based on the Options model but incorporated individually. The Options model also includes Home Ownership Alternatives, a separate non-profit financial corporation which exists to finance specific Options functions.

None of the individual components of the Options model are unique to Options. The model combines innovations in affordable housing finance, co-operative housing, and conventional cost-saving mechanisms to provide high-quality condominium units at a lower cost than private developers. Options is designed to function without government subsidies, and many of their buildings have provided low-cost home ownership to households without government assistance. However because different levels of government recognize the 
importance of affordable home ownership opportunities, certain advantages have been given to Options over the years, such as the deferral of development permit fees, building permit fees and development charges. This does not invalidate the ability of the model to function without subsidies, but does increase the affordability of the units. Furthermore, because government subsidies are not required, Options units can be occupied by anyone who is able to qualify for a mortgage.

Options is an award winning model, having received recognition from the Canadian Mortgage and Housing Corporation, an assortment of non-profits, and numerous municipalities.

\section{How the Options Model Works}

Options, operating as a development consultant, seeks out potential development sites, and following a feasibility analysis, determines a site to be appropriate for an Options-style development. Options prefers to develop on sites that are not regarded as premium by private developers, but are nonetheless close to transit and amenities. Individuals from a previous Options development volunteer to form and incorporate a new co-operative housing development corporation (the Co-op), which becomes the developer. The Co-op officially hires Options as the development consultant for the project at a nominal fee, and while the Co-op must enter into any associated legal agreement directly, and is liable as such, the approvals, contracts, and construction financing are all negotiated and arranged by Options, acting as the development consultant. 
Future owners of the units become members of the Co-op by paying a $\$ 100$ fee, usually paid at an informal information session and for which they receive an information package about Options and the proposed development. Before construction begins, a 75-percent presale target must be reached, and construction and registration operate just like a conventional private development. Options acts as the project coordinator until construction is complete, and following completion, the project is registered as a condominium, a condominium corporation is established, and a board of directors is elected. Following registration, and the completion of all the contractual obligations of the Co-op, it dissolves and has no further role in the project. Mortgage registrations occur by the individual purchasers, and the registration of a 2nd mortgage, a key feature of the Options model and mandatory on all units, is assigned to Home Ownership Alternatives.

\section{How Options Creates Affordable Home Ownership Opportunities}

There are three primary differences between the development of a conventional forprofit condominium building and an Options development that increase the affordability of units.

\section{Lower Production Costs}

The building itself is produced at a lower cost. Options combines several modest costsaving measures to produce significant savings on the total cost of production. Compared with a roughly equivalent unit in a for-profit development, Options can produce a unit for around 15 to 17 percent less than a private developer (Canadian Urban Institute, 2005). They do this by using modest finishes in the units and common areas, avoiding expensive and luxurious building 
amenities that are expensive to build and maintain, and focusing on affordable units without building penthouses or luxury suites. In Toronto, Options uses Delterra, the construction arm of Tridel, to build its Toronto projects. There have never been issues of quality or durability, indicating that modest should not be confused with cheap or low-quality.

Additionally, marketing costs, which account for approximately 4-6 percent of the cost of a unit in a private development, are limited to $\$ 2,500$ per unit in an Options development (Labbe, 2014). Information sessions are typically run by volunteers and staff in small venues and word-of-mouth is used to attract new purchasers. Options does not build model suites or undertake media campaigns the way private developers typically do. Only recently, as the organization has grown and has more resources at its disposal, has it begun to advertise in places like the Toronto subway system or through internet marketing.

\section{The 2nd Mortgage}

The most complex feature of an Options development from a buyer's perspective is the 2nd mortgage. The 2 nd mortgage is essentially the difference between how much the unit cost to build and its appraised market value; the difference between the basic cost price and the basic purchase price.

The basic cost price of a unit is the estimated cost of construction, established by the Co-op, pro-rated for each unit, and adjusted for certain premiums such as higher floors or corner units. The basic purchase price of a unit is determined by an independent appraisal of the unit, and represents the expected market value of the unit. The 2 nd mortgage is, as mentioned, the basic purchase price less the basic cost price. An owner of an Options units 
always starts with two mortgages: a first mortgage with a conventional mortgage broker and a 2nd mortgage assigned to Home Ownership Alternatives.

The second mortgage is typically around 15 percent above the basic cost price. It may be discharged at any point, and research indicates that 20-30 percent of second mortgages on any given project are typically discharged as soon as the unit closes (Canadian Urban Institute, 2005). However for 2 nd mortgages not immediately discharged, no payments on either the principal or interest of the second mortgage are due until either the first purchaser sells the unit, or they rent the unit out for a period of longer than two years. At that point, both principal and interest are due in full.

When the 2 nd mortgage becomes due, interest is defined as the lesser of two options. The first option is eight percent interest, compounded annually. The second option is a shared appreciation mortgage, similar to the Attainable Home Ownership Program in Calgary, whereby the owner repays in interest a share of the increase in property value. For example, if the 2 nd mortgage on a unit is $\$ 20,000$, and upon sale the unit appreciated by 20 percent, fully repaying the 2 nd mortgage would cost $\$ 20,000$ in principal and $\$ 4,000(20,000 \times 20 \%)$ in interest, for a total of $\$ 24,000$.

The 2 nd mortgage is only a requirement of the initial purchaser of the unit. Following the sale by its first owner, an Options unit behaves no differently than any other market condominium.

\section{Lower Monthly Fees}

Options developments save money on construction costs by including fewer common amenities than private developments, and this also contributes to ongoing cost savings for 
owners. With fewer common amenities, ongoing maintenance costs and utilities are approximately 10-20 percent less than in private developments (Canadian Urban Institute, 2005).

\section{Additional Cost Saving Mechanisms}

There are a number of other cost-saving mechanisms that Options uses that contribute to the overall cost savings on individual units (Options for Homes, "How to Build...", 2014). These include:

- Finance - Through support from government, the Options network, and Home Ownership Alternatives, purchasers are able to get lower interest rates and developments can defer fees and have access to pre-development financial support.

- Government Support - The deferral of municipal fees and expenses, access to surplus lands, and planning policy support all contribute to increased affordability. These are not considered direct subsidies to the organization.

- Ongoing Operating Costs - Beyond lower maintenance fees, owner education, access to car sharing programs, and access to a national network for insurance and other carrying costs all improve the ongoing affordability of Options units.

\section{Site Selection}

One of the keys to residential development of any kind is securing the right land for a development. Ideally, Options developments are built on peripheral lands away from more expensive real estate markets. In the early stages, Options was extremely successful at securing less-desired lands that were in close proximity to downtown Toronto, and their model thrived 
because of it. The units were desirable, and have since appreciated substantially in value. These include units close to Toronto's Distillery District, High Park, and developments built within minutes of major subway lines. As ideal Options land becomes more limited in supply, developments are being built further from downtown. The lack of available land that suits Options developments is likely to be a challenge moving forward, not only in Toronto but also in other expensive real estate markets such as Metro Vancouver.

\section{Home Ownership Alternatives (HOA)}

HOA is a separate non-profit corporation which holds all the 2 nd mortgages of individual purchasers in Options developments (Home Ownership Alternatives, 2014). While the function of HOA is to hold the 2nd mortgages, the goal of HOA is to accumulate capital, and use the proceeds of the 2 nd mortgages to invest in future affordable housing developments. Over time, HOA has generated sizable amounts of mortgages receivable, as well as a sizable cash position. As 2 nd mortgages are repaid, and the conversion from mortgages receivable to cash occurs, HOA can provide financial assistance to new affordable housing projects. The assistance is typically given during the pre-development stage of projects to assist with cash-flow requirements prior to construction financing or condominium registration. This operates no differently than the deferral of development and building permit fees by municipalities: it isn't required to make the model work, but does increase the affordability of units.

$\mathrm{HOA}$ is a crucial link to the overall mission of Options, to not only create but also sustain affordable home ownership opportunities for low to middle income households. As units are sold, or owners voluntarily pay back their 2 nd mortgages, HOA's ability to further assist projects 
is enhanced, and the effect is twofold. First, it perpetuates a virtuous cycle: HOA supports additional projects, those projects generate more mortgage receivables or cash, and HOA uses those proceeds to support additional projects. Second, as mortgages receivable are converted into cash, HOA has a greater ability to target individuals and households who would not normally qualify for an Options unit by providing additional down payment assistance, both to qualify for a mortgage and to lower the monthly carrying costs of the mortgage.

\section{Critiques and Limitations of Options for Homes}

The literature on Options is limited, despite the organizations size and longevity as a housing developer in Canada's biggest city. The most detailed study was conducted nearly a decade ago, when in 2005 the Toronto Community Housing Corporation retained the Canadian Urban Institute to undertake a study of the Options model. The study validated the Options model, and concluded that Options developments provided below market home ownership opportunities for the households that purchase units.

Additional critiques and limitations will be addressed throughout the remainder of the report, especially as they relate to the potential for Options developments in Metro Vancouver, but the primary critique of Options is that the benefits of affordability accrue almost exclusively to the first purchaser (Canadian Urban Institute, 2005; Metro Vancouver, 2012). Once the unit is sold to the first purchaser, it behaves just like a market condominium. As an Options unit tends to be a modest unit in a building with modest amenities, it will be slightly more affordable than comparable units, and condominium fees will still be lower than comparable buildings, but those are the only ways in which an Options unit remains a below market unit. 
Only the first purchaser has access to a second mortgage, and there are no restrictions on the re-sale price of the unit.

\section{Unit Affordability vs. Household Affordability}

The opportunity a first purchaser is given in an Options development to profit from the sale of the unit illustrates an important distinction in affordable home ownership policy. "Unit" affordability ensures that a unit remains below-market for an extended period of time, and is common in government subsidized affordable housing programs. When sold, the re-sale price must remain below market. This ensures that housing is below market for whoever occupies the unit, but only for as long as they occupy the unit.

A different approach, and the one used by Options, is to provide "household" affordability. If re-sale restrictions are placed on a unit, housing is no longer affordable once the unit is sold or vacated, as a household is unable to capitalize on the appreciated value of their unit. Unless they have access to another below-market home ownership opportunity, or have increased their income relative to the cost of housing, they are once again priced out of the housing market. An Options unit provides a household with the opportunity to access the housing market for life. Either they remain in the Options unit, or sell the Options unit at a market rate and use the increase in equity to access the conventional housing market. 


\section{Section 3 - High-Rise Options in Metro Vancouver}

As outlined in the previous section, there are numerous cost-saving mechanisms that Options uses to produce below market home ownership opportunities. This section will focus on three primary cost saving measures - a reduction in construction costs, a reduction in marketing costs, and the near-elimination of developer profit - and the savings they would create in the upfront cost of a unit when compared with a private development of the same size.

The scenarios include a 10 percent savings for Options in hard costs through modest finishes. Typically, Options can save as much as 15 to 17 percent of hard costs (Canadian Urban Institute, 2005), but in Toronto this is assisted by a strong relationship with a builder, and no such relationship exists in Metro Vancouver. By establishing strong relationships with interested municipalities and selling them on the benefits of the model, Options may be able to defer municipal fees, get a reduction in development charges, or have access to surplus municipal lands; this would reduce loan interest charges, soft costs, and land costs. But no such relationships have been fully established in Metro Vancouver. Additionally, Options typically saves costs on land due to the avoidance of premium sites, but in Metro Vancouver they would be competing directly with private developers for limited developable land, and so no land cost savings are factored into the scenarios. A slight savings in soft costs is factored in to the scenarios, as they are calculated as a proportion of the hard costs which, as mentioned, are discounted by 10 percent. It is assumed these soft cost savings would be possible through 
modest building designs and a discount on legal, insurance, and administrative costs obtained by accessing existing Options resources.

The figures presented are estimates only, and no quantity surveyor or commissioned real estate reports were used to develop the development Pro Formas. Pro Formas do not include either the costs or revenues associated with parking or lockers, and exclude any unit extras which Options offers at the discretion of purchasers. Findings are presented to demonstrate the magnitude of the savings possible from these measures, and where in Metro Vancouver Options could create the most comparable savings. Furthermore, these are presented as hypothetical developments. They are not based on specific sites, do not address the availability of assembled land, and are loosely based on height and density expectations in each municipality. Further details regarding the assumptions and sources can be found in the Appendix. 


\section{Downtown Vancouver}

A 45-storey Options tower in Downtown Vancouver would save $\$ 182$ per square foot compared to a private development, but would still cost nearly $\$ 700$ per square foot to build.

\begin{tabular}{|c|c|c|}
\hline Options For Homes Feasibility & \multicolumn{2}{|c|}{ Table 1 - Downtown Vancouver } \\
\hline Hypothetical Project Statistics & Options & Private Condo \\
\hline Floors & 45 & 45 \\
\hline Units & 540 & 540 \\
\hline Average Net Unit Size & 689 & 689 \\
\hline Gross to Net Efficiency & $82 \%$ & $82 \%$ \\
\hline Total Saleable Area & 372,060 & 372,060 \\
\hline Gross Residential Area (GRA) & 453,732 & 453,732 \\
\hline \multicolumn{3}{|l|}{ Expenditures } \\
\hline Blended Construction Cost (per sf) & $\$ 258.50$ & $\$ 258.50$ \\
\hline Savings through design and modest finishes & $10 \%$ & N/A \\
\hline Total Construction Cost & $\$ 105,560,682$ & $\$ 117,289,646$ \\
\hline Soft Cost (\% of Hard Costs) & $55 \%$ & $55 \%$ \\
\hline Total Soft Costs & $\$ 58,058,375$ & $\$ 64,509,305$ \\
\hline Marketing Savings (per unit) & $-\$ 22,500$ & N/A \\
\hline Total Marketing Savings & $-\$ 12,150,000$ & N/A \\
\hline Land Cost (per buildable sf) & $\$ 220$ & $\$ 220$ \\
\hline Total Land Cost & $\$ 99,820,976$ & $\$ 99,820,976$ \\
\hline Developer Profit (\% of project cost) & $2 \%$ & $15 \%$ \\
\hline Total Developer Profit & $\$ 5,025,801$ & $\$ 42,242,989$ \\
\hline Project Contingency (\% of Hard Costs) & $2.82 \%$ & $2.82 \%$ \\
\hline Total Project Contingency & $\$ 2,976,811$ & $\$ 3,307,568$ \\
\hline Total Project Cost (TPC) & $\$ 259,292,644$ & $\$ 327,170,485$ \\
\hline Total Project Cost per saleable square foot & $\$ 697$ & $\$ 879$ \\
\hline $\begin{array}{l}\text { Options Savings (\$ per sf) } \\
\text { Options Savings (\%) }\end{array}$ & & $\begin{array}{r}\$ 182 \\
21 \%\end{array}$ \\
\hline
\end{tabular}




\section{Central Burnaby}

A 25-storey Options tower in Central Burnaby would cost $\$ 522$ per square foot, a 23 percent savings over a private development, or a difference of $\$ 155$ per square foot.

\begin{tabular}{|c|c|c|}
\hline Options For Homes Feasibility & Table 2 - Centr & al Burnaby \\
\hline Hypothetical Project Statistics & Options & Private Condo \\
\hline Floors & 25 & 25 \\
\hline Units & 300 & 300 \\
\hline Average Net Unit Size & 689 & 689 \\
\hline Gross to Net Efficiency & $82 \%$ & $82 \%$ \\
\hline Total Saleable Area & 206,700 & 206,700 \\
\hline Gross Residential Area (GRA) & 252,073 & 252,073 \\
\hline Expenditures & & \\
\hline Blended Construction Cost (per sf) & $\$ 235.00$ & $\$ 235.00$ \\
\hline Savings through design and modest finishes & $10 \%$ & $\mathrm{~N} / \mathrm{A}$ \\
\hline Total Construction Cost & $\$ 53,313,476$ & $\$ 59,237,195$ \\
\hline Soft Cost (\% of Hard Costs) & $55 \%$ & $55 \%$ \\
\hline Total Soft Costs & $\$ 29,322,412$ & $\$ 32,580,457$ \\
\hline Marketing Savings (per unit) & $-\$ 22,500$ & $\mathrm{~N} / \mathrm{A}$ \\
\hline Total Marketing Savings & $-\$ 6,750,000$ & $\mathrm{~N} / \mathrm{A}$ \\
\hline Land Cost (per buildable sf) & $\$ 113$ & $\$ 113$ \\
\hline Total Land Cost & $\$ 28,484,268$ & $\$ 28,484,268$ \\
\hline Developer Profit (\% of project cost) & $2 \%$ & $15 \%$ \\
\hline Total Developer Profit & $\$ 2,087,403$ & $\$ 18,045,288$ \\
\hline Project Contingency (\% of Hard Costs) & $2.82 \%$ & $2.82 \%$ \\
\hline Total Project Contingency & $\$ 1,503,440$ & $\$ 1,670,489$ \\
\hline Total Project Cost (TPC) & $\$ 107,960,999$ & $\$ 140,017,698$ \\
\hline Total Project Cost per saleable square foot & $\$ 522$ & $\$ 677$ \\
\hline Options Savings (\$ per sf) & & $\$ 155$ \\
\hline Options Savings (\%) & & $23 \%$ \\
\hline
\end{tabular}




\section{Central Surrey}

A tower in Central Surrey represents the greatest proportional savings of the four hypothetical scenarios, a $26 \%$ savings compared to a private development.

\begin{tabular}{|c|c|c|}
\hline Options For Homes Feasibility & Table 3 - Centr & al Surrey \\
\hline Hypothetical Project Statistics & Options & Private Condo \\
\hline Floors & 20 & 20 \\
\hline Units & 240 & 240 \\
\hline Average Net Unit Size & 689 & 689 \\
\hline Gross to Net Efficiency & $82 \%$ & $82 \%$ \\
\hline Total Saleable Area & 165,360 & 165,360 \\
\hline Gross Residential Area (GRA) & 201,659 & 201,659 \\
\hline Expenditures & & \\
\hline Blended Construction Cost (per sf) & $\$ 203.70$ & $\$ 203.70$ \\
\hline Savings through design and modest finishes & $10 \%$ & $\mathrm{~N} / \mathrm{A}$ \\
\hline Total Construction Cost & $\$ 36,970,060$ & $\$ 41,077,844$ \\
\hline Soft Cost (\% of Hard Costs) & $55 \%$ & $55 \%$ \\
\hline Total Soft Costs & $\$ 20,333,533$ & $\$ 22,592,814$ \\
\hline Marketing Savings (per unit) & $-\$ 22,500$ & $\mathrm{~N} / \mathrm{A}$ \\
\hline Total Marketing Savings & $-\$ 5,400,000$ & $\mathrm{~N} / \mathrm{A}$ \\
\hline Land Cost (per buildable sf) & $\$ 26$ & $\$ 26$ \\
\hline Total Land Cost & $\$ 5,243,122$ & $\$ 5,243,122$ \\
\hline Developer Profit (\% of project cost) & $2 \%$ & $15 \%$ \\
\hline Total Developer Profit & $\$ 1,142,934$ & $\$ 10,337,067$ \\
\hline Project Contingency (\% of Hard Costs) & $2.82 \%$ & $2.82 \%$ \\
\hline Total Project Contingency & $\$ 1,042,556$ & $\$ 1,158,395$ \\
\hline Total Project Cost (TPC) & $\$ 59,332,204$ & $\$ 80,409,242$ \\
\hline Total Project Cost per saleable square foot & $\$ 359$ & $\$ 486$ \\
\hline $\begin{array}{l}\text { Options Savings (\$ per sf) } \\
\text { Options Savings (\%) }\end{array}$ & & $\begin{array}{l}\$ 127 \\
26 \%\end{array}$ \\
\hline
\end{tabular}




\section{Central Coquitlam}

A smaller, 15-storey Options tower in Central Coquitlam would cost $\$ 404$ per square foot to build, representing a $25 \%$ savings when compared to a private development.

\begin{tabular}{|c|c|c|}
\hline Options For Homes Feasibility & \multicolumn{2}{|c|}{ Table 4 - Central Coquitlam } \\
\hline Hypothetical Project Statistics & Options & Private Condo \\
\hline Floors & 15 & 15 \\
\hline Units & 180 & 180 \\
\hline Average Net Unit Size & 689 & 689 \\
\hline Gross to Net Efficiency & $82 \%$ & $82 \%$ \\
\hline Total Saleable Area & 124,020 & 124,020 \\
\hline Gross Residential Area (GRA) & 151,244 & 151,244 \\
\hline \multicolumn{3}{|l|}{ Expenditures } \\
\hline Blended Construction Cost (per sf) & $\$ 203.70$ & $\$ 203.70$ \\
\hline Savings through design and modest finishes & $10 \%$ & $\mathrm{~N} / \mathrm{A}$ \\
\hline Total Construction Cost & $\$ 27,727,545$ & $\$ 30,808,383$ \\
\hline Soft Cost (\% of Hard Costs) & $55 \%$ & $55 \%$ \\
\hline Total Soft Costs & $\$ 15,250,150$ & $\$ 16,944,611$ \\
\hline Marketing Savings (per unit) & $-\$ 22,500$ & N/A \\
\hline Total Marketing Savings & $-\$ 4,050,000$ & N/A \\
\hline Land Cost (per buildable sf) & $\$ 63$ & $\$ 63$ \\
\hline Total Land Cost & $\$ 9,452,744$ & $\$ 9,452,744$ \\
\hline Developer Profit (\% of project cost) & $2 \%$ & $15 \%$ \\
\hline Total Developer Profit & $\$ 967,609$ & $\$ 8,580,861$ \\
\hline Project Contingency (\% of Hard Costs) & $2.82 \%$ & $2.82 \%$ \\
\hline Total Project Contingency & $\$ 781,917$ & $\$ 868,796$ \\
\hline Total Project Cost (TPC) & $\$ 50,129,964$ & $\$ 66,655,394$ \\
\hline Total Project Cost per saleable square foot & $\$ 404$ & $\$ 537$ \\
\hline $\begin{array}{l}\text { Options Savings (\$ per sf) } \\
\text { Options Savings (\%) }\end{array}$ & & $\begin{array}{r}\$ 133 \\
25 \%\end{array}$ \\
\hline
\end{tabular}




\section{High-Rise Analysis}

In each of the hypothetical projects, stacking the three cost-saving measures - lower construction costs, lower marketing costs, and less profit - created substantial savings when compared to private developments. The locations with the least expensive land, Surrey and Coquitlam, experienced the greatest proportional savings. Where land is the most expensive, Downtown Vancouver and Central Burnaby, land costs take up a greater proportion of the total project cost. Because the costs of land were determined to be the same in both Options and private developments, in these scenarios the components of the projects that Options realizes savings on takes up a smaller proportion of the total cost. Efficiencies and average unit sizes remained static regardless of project size, and therefore increased densities did not create additional savings.

This very preliminary analysis suggests that less expensive land leads to greater proportional savings compared to private developments, a strategy that Options actively employs. The next stage of analysis will be to consider the carrying costs required to purchase units in each hypothetical development. This will introduce the additional cost saving measure of lower condominium fees into an Options development, as well as the benefits of the $2^{\text {nd }}$ mortgage. 


\section{Section 4-Options Carrying Costs and Affordability}

Compared with private developments, Options would be able to realize substantial production cost savings. Lower production costs lead to lower unit prices, which lead to lower carrying costs through lower mortgage payments. Furthermore, because of the modest common amenities the buildings are less expensive to operate and maintain, and as a result Options condo fees are typically 10-20 percent lower than comparable private developments (Canadian Urban Institute, 2005).

Options purchasers only need to finance the basic cost price of a unit, as the remainder, known as the basic purchase price, is financed by a $2^{\text {nd }}$ mortgage covered by Home Ownership Alternatives. The basic cost price of an Options unit is the cost of production, taking into consideration certain premiums or discounts based on the specific unit. However the following analysis assumes no premium or discount on units, and no appliances or extras that are options for purchasers: the basic cost price is the cost per square foot to produce the unit.

\section{Carrying Costs - Central Burnaby}

High-rise Options units in Burnaby in the hypothetical projects from the previous section could be constructed for a total of $\$ 522$ per square foot, 23 percent less than $\$ 677$ per square foot for private developments. This is comparable to the market for high-rise condominiums in Central Burnaby, based on the list prices of newly built condominiums on MLS. 
Table 5

\begin{tabular}{|rrr|}
\hline Central Burnaby - High-Rise Built 2010 to 2014 \\
\hline Sq Ft & Price & Price $/$ sf \\
\hline 1,150 & $\$ 928,000$ & $\$ 807$ \\
842 & $\$ 609,000$ & $\$ 723$ \\
899 & $\$ 560,900$ & $\$ 624$ \\
842 & $\$ 662,000$ & $\$ 786$ \\
459 & $\$ 269,900$ & $\$ 588$ \\
605 & $\$ 429,900$ & $\$ 711$ \\
\hline & Average & $\$ 706$ \\
\hline
\end{tabular}

Source: MLS.ca, 2014

Table 6 below outlines the basic financial components of an Options unit in Central

Burnaby.

Table 6

Central Burnaby - Options Units @ \$522 per sq ft

\begin{tabular}{|lrrrr|}
\hline Unit & Sq Ft & Basic Cost Price & Basic Purchase Price & 2nd Mortgage \\
\hline Studio & 489 & $\$ 255,408$ & $\$ 293,720$ & $\$ 38,311$ \\
1-bed & 589 & $\$ 307,639$ & $\$ 353,785$ & $\$ 46,146$ \\
1-bed and Den & 689 & $\$ 359,870$ & $\$ 413,850$ & $\$ 53,980$ \\
2-bed & 789 & $\$ 412,101$ & $\$ 473,916$ & $\$ 61,815$ \\
\hline
\end{tabular}

The basic cost price of a unit ranges from $\$ 255,408$ to $\$ 412,101$. The basic purchase price is calculated at 15 percent above the basic cost price, an estimate typical of most Options developments (Canadian Urban Institute, 2005). The $2^{\text {nd }}$ mortgage is the difference between the basic purchase price and the basic cost price. Table 7 calculates the mortgage payments required for each of the units. 
Table 7

\begin{tabular}{|lrrr|}
\hline \multicolumn{4}{|l|}{ Central Burnaby - Options Units @ $\$ \mathbf{5 2 2}$ per sq ft } \\
\hline Unit & Down Payment & Mortgage & Mortgage Payments \\
\hline Studio & $\$ 20,432.68$ & $\$ 234,976$ & $\$ 1,240$ \\
1-bed & $\$ 17,689.26$ & $\$ 289,950$ & $\$ 1,530$ \\
1-bed and Den & $\$ 20,692.52$ & $\$ 339,177$ & $\$ 1,790$ \\
2-bed & $\$ 23,695.79$ & $\$ 388,405$ & $\$ 2,050$ \\
\hline
\end{tabular}

The down payment is calculated as 5 percent of the purchase price, and the purchase price less the $2^{\text {nd }}$ mortgage and down payment equals the amount that must be financed by the purchaser. The mortgages are calculated using a 4 percent interest rate and are amortized over 25 years. The term is typical, and the interest rate is slightly higher than the national average to reflect potential future increases in rates that would increase the carrying costs of units (CanEquity, 2014).

Table 8 uses only the monthly mortgage payments and strata fees to calculate the monthly carrying costs of an Options unit, and excludes utilities, maintenance, and any other fees or costs that may be associated with home ownership.

Table 8

\begin{tabular}{|c|c|c|c|c|c|}
\hline \multicolumn{6}{|c|}{ Central Burnaby - Carrying Costs } \\
\hline Unit & $\mathrm{Sq} \mathrm{Ft}$ & Strata Fees (per sf) & Monthly Fees & Mortgage Payments & Total \\
\hline Studio & 489 & $\$ 0.29$ & $\$ 142$ & $\$ 1,240$ & $\$ 1,382$ \\
\hline 1-bed & 589 & $\$ 0.29$ & $\$ 171$ & $\$ 1,530$ & $\$ 1,701$ \\
\hline 1-bed and Den & 689 & $\$ 0.29$ & $\$ 200$ & $\$ 1,790$ & $\$ 1,990$ \\
\hline 2-bed & 789 & $\$ 0.29$ & $\$ 229$ & $\$ 2,050$ & $\$ 2,279$ \\
\hline
\end{tabular}

As mentioned, condo fees are typically 10-20 percent lower in Options developments.

Strata fees in Burnaby average \$0.34 per square foot for condo high rises (Real Estate Weekly, 2013). The $\$ 0.29$ used is 15 percent lower than the average rate, a reasonable estimate for an Options development. 


\section{Carrying Costs - Vancouver, Surrey, Coquitlam}

The total carrying costs for the other three hypothetical developments, developed using the same formulas as the Burnaby project, are listed in Tables 9, 10, and 11.

Table 9

\begin{tabular}{|c|c|c|c|c|c|}
\hline Unit & $\mathrm{Sq} F \mathrm{t}$ & Strata Fees (per sf) & Monthly Fees & Mortgage Payments & Total \\
\hline Studio & 489 & $\$ 0.40$ & $\$ 196$ & $\$ 1,655$ & $\$ 1,851$ \\
\hline 1-bed & 589 & $\$ 0.40$ & $\$ 236$ & $\$ 2,042$ & $\$ 2,278$ \\
\hline 1-bed and Den & 689 & $\$ 0.40$ & $\$ 276$ & $\$ 2,389$ & $\$ 2,664$ \\
\hline 2-bed & 789 & $\$ 0.40$ & $\$ 316$ & $\$ 2,735$ & $\$ 3,051$ \\
\hline
\end{tabular}

Table 10

\begin{tabular}{|c|c|c|c|c|c|}
\hline \multicolumn{6}{|c|}{ Central Surrey - Carrying Costs } \\
\hline Unit & $\mathrm{Sq} \mathrm{Ft}$ & Strata Fees (per sf) & Monthly Fees & Mortgage Payments & Total \\
\hline Studio & 489 & $\$ 0.30$ & $\$ 147$ & $\$ 852$ & $\$ 999$ \\
\hline 1-bed & 589 & $\$ 0.30$ & $\$ 177$ & $\$ 1,051$ & $\$ 1,228$ \\
\hline 1-bed and Den & 689 & $\$ 0.30$ & $\$ 207$ & $\$ 1,230$ & $\$ 1,437$ \\
\hline 2-bed & 789 & $\$ 0.30$ & $\$ 237$ & $\$ 1,408$ & $\$ 1,645$ \\
\hline
\end{tabular}

Table 11

\begin{tabular}{|c|c|c|c|c|c|}
\hline Unit & $\mathrm{Sa} \mathrm{Ft}_{\mathrm{H}} \mathrm{C}_{2}$ & Strata Eoos (nor cf) & Montbly Eons & & \\
\hline Studio & 489 & $\$ 0.28$ & $\$ 137$ & $\$ 960$ & $\$ 1097$ \\
\hline 1-bed & 589 & $\$ 0.28$ & $\$ 165$ & $\$ 1,184$ & $\$ 1,349$ \\
\hline 1-bed and Den & 689 & $\$ 0.28$ & \$193 & $\$ 1,385$ & $\$ 1,578$ \\
\hline 2-bed & 789 & $\$ 0.28$ & $\$ 221$ & $\$ 1,587$ & $\$ 1,808$ \\
\hline
\end{tabular}

\section{Affordability}

The carrying costs for each unit in each hypothetical project are summarized in in Table

12. 
Table 12

\begin{tabular}{|lrrrr|}
\hline Total Carrying Costs & \multicolumn{4}{l|}{} \\
\hline Unit & Vancouver & Burnaby & Surrey & Coquitlam \\
\hline Studio & $\$ 1,851$ & $\$ 1,382$ & $\$ 999$ & $\$ 1,097$ \\
1-bed & $\$ 2,278$ & $\$ 1,701$ & $\$ 1,228$ & $\$ 1,349$ \\
1-bed and Den & $\$ 2,664$ & $\$ 1,990$ & $\$ 1,437$ & $\$ 1,578$ \\
2-bed & $\$ 3,051$ & $\$ 2,279$ & $\$ 1,645$ & $\$ 1,808$ \\
\hline
\end{tabular}

As discussed earlier, to avoid housing stress shelter costs must not equal 30 percent or more of a households before tax income. For a unit to be attainable while avoiding housing stress, households must earn a minimum of the incomes listed in Table 13.

Table 13

\begin{tabular}{|c|c|c|c|c|}
\hline \multicolumn{5}{|c|}{ Minimum Income (Annual Unit Carrying Costs = $30 \%$ of Before-Tax Income) } \\
\hline Unit & Vancouver & Burnaby & Surrey & Coquitlam \\
\hline Studio & $\$ 74,020$ & $\$ 55,284$ & $\$ 39,949$ & $\$ 43,871$ \\
\hline 1-bed & $\$ 91,107$ & $\$ 68,051$ & $\$ 49,123$ & $\$ 53,973$ \\
\hline 1-bed and Den & $\$ 106,575$ & $\$ 79,605$ & $\$ 57,463$ & $\$ 63,137$ \\
\hline 2-bed & $\$ 122,044$ & $\$ 91,158$ & $\$ 65,803$ & $\$ 72,300$ \\
\hline Median Househ & Metro & & & $\$ 63,347$ \\
\hline
\end{tabular}

Highlighted incomes are below median household income

The income statistics used are for all of Metro Vancouver, and not for each individual municipality. Metro Vancouver considers low to moderate income households have incomes between 50 and 80 percent of the median household income; in Metro Vancouver that is between $\$ 31,674$ and $\$ 50,678$ (Metro Vancouver, 2014). The highlighted cells in Table 13 represent units that could be afforded by median income earners. Median income earners are excluded from any of the 2-bedroom units, and low to moderate income households could only afford either a studio or 1-bedroom apartment in Surrey, or a studio apartment in Coquitlam. 


\section{Analysis - Carrying Costs and Affordability}

The construction of Options-style developments in Metro Vancouver would create cost effective home ownership opportunities, especially when compared with private developments. However units in the hypothetical projects would still be out of range for low to moderate income households in Metro Vancouver, and only the smaller units would be at a price point attainable for median income earners. The next section will explore further cost saving measures in an attempt to create units that are attainable for a wider range of income earners. 


\section{Section 5 - Mid-Rise Options in Metro Vancouver}

A further reduction in land costs and construction costs would assist in the creation of cost effective home ownership opportunities. To achieve lower construction costs and lower land costs, developments would have to move away from Vancouver and Burnaby, away from desirable locations, and shift from concrete tower construction to wood-frame construction. This would result in lower density developments further from transit and amenities, but would potentially attract low to moderate income earners. Of the four municipalities chosen, land is most affordable in Surrey and Coquitlam, and focus will narrow to those two locations using lower land costs and assuming a less central location in each. Further cost savings are achieved by the shift to wood-frame buildings, permitted for up to 6-storey developments in British Columbia (BC Government, 2009). Efficiencies are lowered to account for the change from highrise to mid-rise, and unit sizes are increased by an average of 50 square feet per unit. This represents a shift from the Options model that has had success in Southern Ontario, which relied on a strong relationship with a builder and the economies of scale associated with large concrete condominium buildings to produce cost effective units. 


\section{Surrey and Coquitlam Mid-Rise - Project Cost}

At a total project cost of $\$ 218$ per square foot in Surrey, and $\$ 274$ in Coquitlam, the savings over the previous Options projects are substantial: a 39 percent drop in Surrey, and a 32 percent drop in Coquitlam.

\begin{tabular}{|c|c|c|}
\hline \multirow{2}{*}{ Options For Homes Feasibility } & \multicolumn{2}{|l|}{ Table 14} \\
\hline & Surrey & Coquitlam \\
\hline Hypothetical Project Statistics & Options & Options \\
\hline Floors & 6 & 6 \\
\hline Units & 72 & 72 \\
\hline Average Net Unit Size & 739 & 739 \\
\hline Gross to Net Efficiency & $80 \%$ & $80 \%$ \\
\hline Total Saleable Area & 53,208 & 53,208 \\
\hline Gross Residential Area (GRA) & 66,510 & 66,510 \\
\hline \multicolumn{3}{|l|}{ Expenditures } \\
\hline Blended Construction Cost (per sf) & $\$ 126.10$ & $\$ 126.10$ \\
\hline Savings through design and modest finishes & $10 \%$ & $10 \%$ \\
\hline Total Construction Cost & $\$ 7,548,220$ & $\$ 7,548,220$ \\
\hline Soft Cost (\% of Hard Costs) & $55 \%$ & $55 \%$ \\
\hline Total Soft Costs & $\$ 4,151,521$ & $\$ 4,151,521$ \\
\hline Marketing Savings (per unit) & $-\$ 22,500$ & $-\$ 22,500$ \\
\hline Total Marketing Savings & $-\$ 1,620,000$ & $-\$ 1,620,000$ \\
\hline Land Cost (per buildable sf) & $\$ 16$ & $\$ 60$ \\
\hline Total Land Cost & $\$ 1,064,160$ & $\$ 3,990,600$ \\
\hline Developer Profit (\% of project cost) & $2 \%$ & $2 \%$ \\
\hline Total Developer Profit & $\$ 222,878$ & $\$ 281,407$ \\
\hline Project Contingency (\% of Hard Costs) & $2.82 \%$ & $2.82 \%$ \\
\hline Total Project Contingency & $\$ 212,860$ & $\$ 212,860$ \\
\hline Total Project Cost (TPC) & $\$ 11,579,639$ & $\$ 14,564,607$ \\
\hline Total Project Cost per saleable square foot & $\$ 218$ & $\$ 274$ \\
\hline
\end{tabular}




\section{Surrey and Coquitlam Mid-Rise - Carrying Costs and Affordability}

Those savings translate into significantly lower carrying costs, and have a demonstrable impact on the affordability of units.

Table 15

\begin{tabular}{|lrr|}
\hline Total Carrying Costs & & \\
\hline Unit & Surrey & Coquitlam \\
\hline Studio & $\$ 649$ & $\$ 787$ \\
1-bed & $\$ 797$ & $\$ 967$ \\
1-bed and Den & $\$ 932$ & $\$ 1,131$ \\
2-bed & $\$ 1,067$ & $\$ 1,295$ \\
\hline
\end{tabular}

Table 16

\begin{tabular}{|lrr|}
\hline \multicolumn{4}{|l|}{ Minimum Income (Annual Unit Carrying Costs = 30\% of Before-Tax } \\
\hline Unit & Surrey & Coquitlam \\
\hline Studio & $\$ 25,953$ & $\$ 31,477$ \\
1-bed & $\$ 31,869$ & $\$ 38,680$ \\
1-bed and Den & $\$ 37,280$ & $\$ 45,247$ \\
2-bed & $\$ 42,691$ & $\$ 51,814$ \\
\hline Median Income, Metro Vancouver & $\$ 63,347$ \\
\hline
\end{tabular}

Highlighted incomes are below median household income

Every unit is attainable for median income earners in Metro Vancouver, and every unit but the 2-bedroom unit in Coquitlam becomes attainable for low to moderate income earners. These changes achieved the desired effect of creating units that would attract a wider range of incomes, but the challenge in the less desirable locations may be in sustaining demand for modest units not typical in lower density neighbourhoods. 


\section{Section 6 - Findings and Recommendations}

The affordable housing issue in Metro Vancouver is well established, and affirmed by the data on housing stress. 46 percent of renters are experiencing housing stress, and for those who would rather own than rent the challenge is twofold: they struggle to pay rent, and the high cost of housing prohibits them from saving for a down payment. This can be helped or hindered by both fluctuating interest rates and the somewhat fluid qualifications required for a mortgage. The struggle for tenants is exacerbated as the population ages.

FIGURE 7: HOUSING STRESS BY TENURE AND AGE GROUP

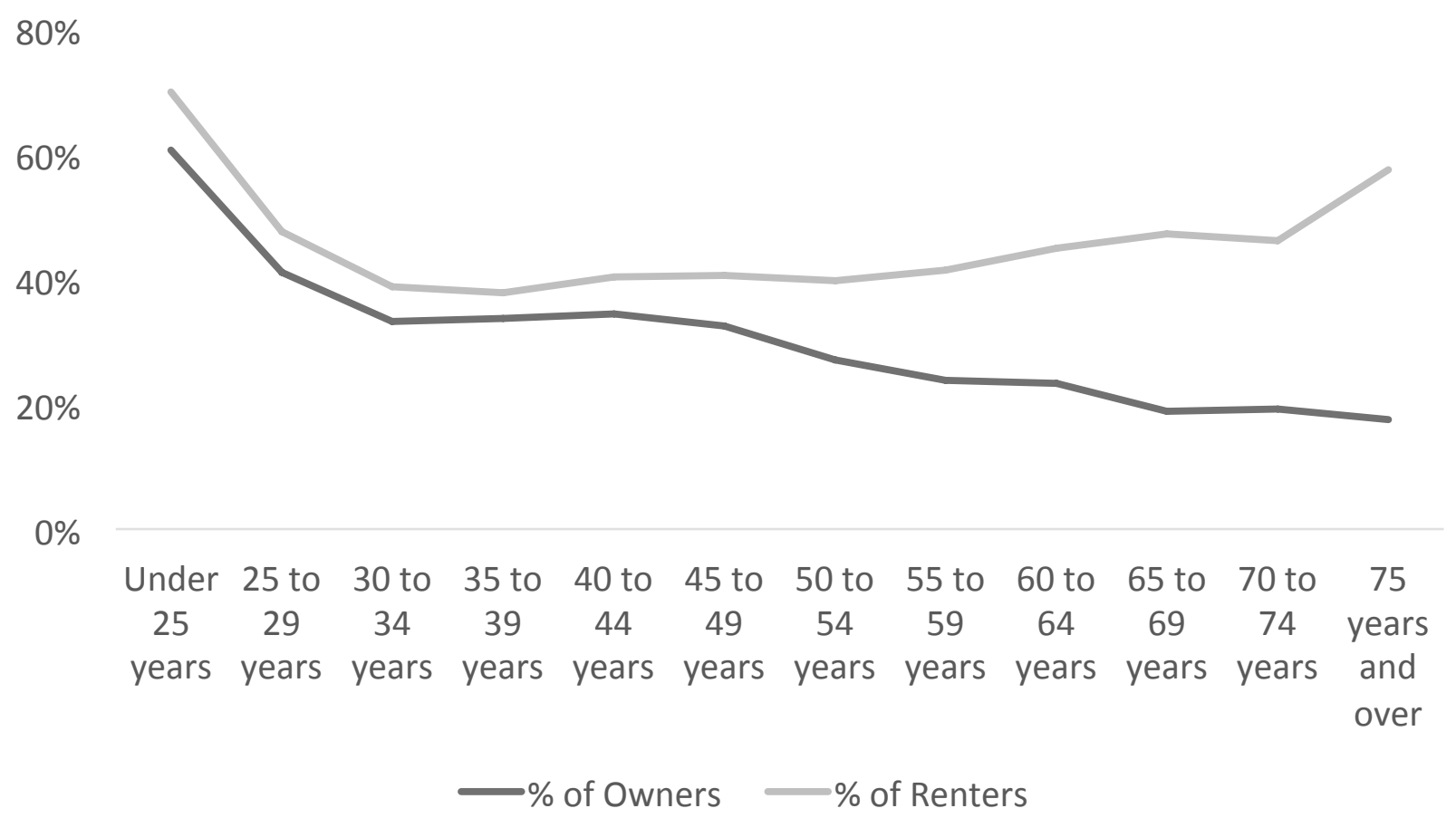

Source: Statistics Canada, 2013 
As revealed by Figure 7, as the population ages, owners become less and less likely to experience housing stress. For many, this is possible because they have paid off their mortgages by the time they reach retirement age. However for renters, after the age of 25 , age has a minimal impact on the presence of housing stress. This emphasizes the importance of ensuring that home ownership opportunities are attainable for a wide range of incomes, to help avoid housing stress that is sustained throughout one's lifetime. One approach to achieving cost effective home ownership opportunities is through a model like Options, which emphasizes home ownership, and ensures affordability at the household level. Households can build equity through Options, and ideally eventually pay off their mortgage to avoid housing stress later in life.

The findings from Section 3 reveal that Options-style developments would achieve significant savings compared to private market developments, especially in municipalities with more affordable land costs. Section 4 demonstrates that despite these comparable savings, Options units would still be unattainable for many Metro Vancouver residents. This illustrates a significant challenge to creating affordable units in Metro Vancouver: the prohibitively high cost of land and construction. Through cheaper land and wood-frame construction, Section 5 demonstrated that affordable units were possible in Options-style developments.

\section{Findings}

Creating Affordable Housing Units through New Housing

Land costs and construction costs have never been higher than they are currently in Metro Vancouver. Even while realizing substantial cost savings over private new-builds, the 
carrying cost of all but three high-rise units in Section 3 were higher than the median shelter cost of owned dwellings in Metro Vancouver (Statistics Canada, 2013). This illustrates the challenge of creating affordability through new housing: even when cost saving measures are employed, new housing units are still less affordable than most of the older housing stock.

\section{Compromising Location for Affordability}

In Section 4 it was demonstrated that cheaper land and construction appears to be the only way to create units that are attainable for low to moderate income earners. However the unit sizes averaged only 739 square feet, and securing demand for small units in less than ideal locations could present an additional challenge for Options. Predictably, avoiding premium sites and more expensive municipality's resulted in more affordable units, but the demand for smaller units is less proven in those markets, and the extra cost of transportation associated with units built on cheaper sites may not be worth the trade-off for low to moderate income earners.

\section{Recommendations}

\section{For Metro Vancouver Municipalities - Deferral of municipal fees and charges}

Affordable housing initiatives should target every point on the housing continuum, from homelessness to market housing, including below-market home ownership. Options for Homes is a model that has a track record of success in Canada, and the creation of cost effective home ownership opportunities in the short-term could alleviate the housing stress felt by many 
households in the long-term. To facilitate the creation of below market units in the region, and to further make those units affordable, Metro Vancouver municipalities should provide organizations willing to produce those units with incentives provided they can demonstrate those incentives will be passed through to the consumer. Waiving or deferring building permit fees, development permit fees, development charges, and other municipal fees and charges would both foster investment in Options-style developments, and provide units that were even more affordable than the examples provided in Sections 4 and 5.

\section{For Municipal, Regional, and Provincial Governments - Leasing of surplus lands}

As was demonstrated earlier, high land costs are extremely prohibitive for the creation of below market units, and a key driver of unaffordability in the region. Instead of conveying land for the development of affordable units, governments should explore the possibility of leasing surplus lands to non-profit organizations for the creation of affordable units. The public sector would retain ownership of the land, but still attract investment to underused, vacant or surplus government property that would be used to alleviate the issue of regional affordability.

3. For Non-Profit Housing Providers - Incorporating 2nd Mortgages into private developments

Given the lack of affordable land in Metro Vancouver, and the prohibitively high cost of acquiring desirable sites, one consideration should be to incorporate some elements of the Options model into existing developments, especially the $2^{\text {nd }}$ mortgage. This would create affordable units in a market building, and developers could consider their inclusion as a community amenity contribution. Habitat for Humanity was recently able to incorporate 8-units into a condominium development in downtown Toronto (Hanes, 2013), and Vancouver already 
uses density bonusing to fund affordable housing initiatives. This approach would take advantage of the economies of scale in larger, private developments while providing low to moderate income earners with access to the housing market.

\section{For Further Research - Determine the effectiveness of Options for Homes affiliates}

Options for Homes has now expanded internationally and domestically and affiliates are breaking away from the standard Options model. Options for Homes Greater Vancouver is building a 30-unit building in Ladner, a distant suburb of Vancouver, and Neighbourhood Concepts, located in Toronto, is building mid-rise buildings instead of high-rises. The Canadian Urban Institute study from 2005 validated the original Options model, but further research on the effectiveness of Options affiliates would help future affiliates in determining where affordability can be created and how to overcome barriers in different jurisdictions with different real estate markets.

5. For Further Research-Outline the benefits of below-market home ownership investment

Public sector officials and politicians have tough decisions to make regarding the disbursement of public funds for housing, and homelessness and social housing are always a priority; targeting moderate income earners with below market home ownership opportunities is a harder sell. However there are short, medium, and long-term benefits to providing these opportunities to households previously priced out of the housing market, and the return on a small investment - leasing surplus lands or waiving charges and fees - can be substantial. This paper was meant to address whether or not affordable units could be produced, and not necessarily the benefit of producing those units. Outlining the benefits for households who 
have access to below market units, and how those benefits impact regional housing markets would assist policy makers in determining when and where the creation of below market home ownership opportunities is a worthy investment. 


\section{Conclusion}

Options for Homes could help alleviate affordability in Metro Vancouver as part of a wider strategy to improve housing affordability for all households, from homelessness to home owners. Having a wider impact on affordability through new housing is an obvious challenge, but the findings demonstrate Options-style development is still in theory likely to produce units at a more affordable price than similar private developments; a worthy pursuit to policy makers in a region with such salient unaffordability. "Below-market" housing that isn't guaranteed to be sustained over the long term is less likely to generate appeal amongst policy makers that sustained "affordable" housing, but nonetheless gives households either initial access to the housing market, or access to larger units for households who living in smaller, less appropriate units. Affordability could further be improved by leasing surplus lands at a nominal rate, and by the waiver or deferral of municipal fees and charges associated with residential development. Efforts on behalf of affordable housing advocates and Options for Homes are also necessary, as the benefits of below-market home ownership need to be clearly outlined if public subsidies are warranted. The Options model is possible without subsidies, but could be targeted to meet other public policy objectives with financial support from the public sector.

The issue of housing affordability in Metro Vancouver isn't going away, but housing can be made less expensively and ownership made more accessible by using a model like Options for Homes. The concern for the region shouldn't only be the one-third of residents currently experiencing housing stress, but the thousands more that will experience the same if the trend of affordability isn't reversed. 


\begin{tabular}{|c|c|}
\hline Options For Homes Feasibility & Pro Forma Assumptions \\
\hline \multicolumn{2}{|l|}{ Hypothetical Project Statistics } \\
\hline Floors & $\begin{array}{l}\text { Standard tower height for each municipality using current development } \\
\text { applications for each. }\end{array}$ \\
\hline Units & 12 units per floor, and no retail component therefore units on all floors. \\
\hline Average Net Unit Size & $\begin{array}{l}\text { Average unit size of previous Options development "Sherbourne" (Canadian } \\
\text { Urban Institute, 2005). }\end{array}$ \\
\hline Gross to Net Efficiency & Rule of Thumb \\
\hline Total Saleable Area & \# of units $x$ average net unit size \\
\hline Gross Residential Area (GRA) & Total saleable area / Efficiency \\
\hline Blended Construction Cost (per sf) & $\begin{array}{l}\text { Butterfield Development Consultants (http://www.bdconsultants.com/) Cost } \\
\text { Index gives a construction cost estimate based on type of development and } \\
\text { location }\end{array}$ \\
\hline Savings through design and modest finishes & $\begin{array}{l}\text { Options typically saves up to } 15 \% \text { of construction costs - this is a modest } \\
\text { savings estimate. }\end{array}$ \\
\hline Total Construction Cost & Construction cost per sf * 0.9 (savings) * GFA \\
\hline Soft Cost (\% of Hard Costs) & Rule of Thumb \\
\hline Total Soft Costs & $.55 *$ Hard Costs \\
\hline Marketing Savings (per unit) & $\begin{array}{l}\text { Savings is based on } \$ 25,000 / \text { unit marketing cost in private development vs. } \\
\$ 2,500 / \text { unit in Options development (Labbe, 2014) }\end{array}$ \\
\hline Total Marketing Savings & Per unit savings * Total units \\
\hline Land Cost (per buildable sf) & $\begin{array}{l}\text { Average taken from a range for each municipality, range from BC Business, } \\
2013 .\end{array}$ \\
\hline Total Land Cost & Land cost per buildable sq ft * GRA \\
\hline Developer Profit (\% of project cost) & Rule of Thumb for private, $2 \%$ for Options (Canadian Urban Institute, 2005) \\
\hline Total Developer Profit & Profit $\% *$ (Land + Marketing Savings + Soft Costs + Hard Costs \\
\hline Project Contingency (\% of Hard Costs) & Rule of thumb (Peiser \& Hamilton, 2012, p171). \\
\hline Total Project Contingency & $2.82 \% *$ total hard costs \\
\hline Total Project Cost (TPC) & Hard Costs + Soft Costs + Marketing Savings + Profit + Contingency \\
\hline Total Project Cost per saleable square foot & JPC / Total Saleable Area \\
\hline
\end{tabular}




\section{References}

Butterfield Development Consultants Ltd. BDC's Cost Index (2014) Web, accessed 5 March 2014. http://www.bdconsultants.com/tools/costindex

CanEquity. Mortgage Rates Comparison (2014): Web, accessed 22 March 2014. http://www.canequity.com/tools/mortgage-rates-comparison/

Clayton, Frank. "Government Subsidies to Homeowners vs Renters in Ontario and Canada." Prepared for the Federation of Rental Housing Providers of Ontario. August 30, 2010.

Duffus, Gavin. "Innovative Affordable Housing Strategies for Vancouver." Digital Commons @ Ryerson. (2012): Web, accessed 13 March 2014.

$<$ http://digitalcommons.ryerson.ca/cgi/viewcontent.cgi?article=1978\&context=dissertations $>$.

Glaeser, Edward. "Rethinking the Federal Bias Towards Homeownership." Cityscape: A Journal of Policy Development and Research. 13.2 (2011): Web, accessed 13 March 2014.

$<$ http://www.huduser.org/portal/periodicals/cityscpe/vol13num2/Cityscape_July2011_rethinki ng.pdf $>$.

Habitat for Humanity. "Build and Ownership Process." Habitat for Humanity Canada. (2014): Web, accessed 13 March 2014. <http://www.habitat.ca/en/how-we-help/building-andownership-process>.

Hanes, T. "Habitat for Humanity families are the winners at 159 Wellesley". The Toronto Star. (Mar 7, 2013). Web, accessed 15 March 2014.

http://www.thestar.com/life/homes/2013/03/07/habitat_for_humanity_families_are_the_win ners_at_159_wellesley.html

Hawtrey, Kim. Affordable Housing Finance. Hampshire, UK: Palgrave MacMillan, 2009. Print. 
Home Ownership Alternatives. What We Do. 2014: Web, accessed 12 March 2014. http://www.hoacorp.ca/about-hoa/our-corporation/what-we-do

Jewkes, M, and L Delgadillo. "Weaknesses of Housing Affordability Indices Used by Practitioners." Association for Financial Counselling and Planning Education. (2010): Web, accessed 15 March 2014.

$<$ http://www.afcpe.org/assets/pdf/volume_21_issue_1/jewkes_delgadillo.pdf $>$.

Labbe, M. (2014, 02 27). Email correspondence with G Plant.

Metro Vancouver, 2012. What Works: Affordable Housing Initiatives in Metro Vancouver Municipalities. Web, accessed 13 March 2014.

$<$ http://www.metrovancouver.org/planning/development/housingdiversity/WhatWorksDocs/C algaryHsg.pdf>.

Metro Vancouver, 2014. Metro Vancouver Housing Data Book. Part of the Sustainable Region Initiative (2014): Web, accessed March 132014.

http://www.metrovancouver.org/planning/development/housingdiversity/HousingDataBookD ocuments/MV_Housing_Data_Book.pdf

Options for Homes. (2012). Why Options? Web, accessed 13 March 2014. http://www.optionsforhomes.ca/why_options/

Options for Homes. (2014). How to build cost-effective housing. Print copy.

Parry, J. (2013, 09 3). “An Affordable High". BC Business (2013): Retrieved from http://www.bcbusiness.ca/real-estate/an-affordable-high

Real Estate Weekly. Condo Maintenance Fees by Size and Age of Unit (2013): Web, accessed March 92014.

http://www.rew.ca/news/condo-maintenance-fees-size-age-unit 
Statistics Canada, 2011 National Household Survey, Statistics Canada Catalogue no. 99-014X2011031.

Statistics Canada. 2013. Vancouver, CMA, British Columbia (Code 933) (table). National Household Survey (NHS) Profile. 2011 National Household Survey. Statistics Canada Catalogue no. 99-004-XWE. Ottawa. Released September 11, 2013.

Weicher, J., \& Katz, B. "Should Congress Limit Mortgage Deduction?" Marketwatch (March 22, 2014): Web, accessed March 242014.

http://www.marketwatch.com/story/should-congress-limit-mortgage-deduction-2014-03-22 